\title{
Development and characterization of porous functionalized collagen scaffolds for delivery of FGF-2
}

\author{
Ia. O. Pokholenko', M. D. Chetyrkina ${ }^{2}$, L. V. Dubey ${ }^{1}$, I. Ya. Dubey ${ }^{1}$, O. V. Moshynets ${ }^{1}$, \\ E. V. Sheludko ${ }^{3}$, S. P. Shpylova ${ }^{1}$, M. I. Degtiarova ${ }^{2}$, V. A. Kordium ${ }^{1}$
}

${ }^{1}$ Institute of Molecular Biology and Genetics, NAS of Ukraine

150,Akademika Zabolotnoho Str., Kyiv, Ukraine, 03680

${ }^{2}$ Educational and Scientific Centre «Institute of Biology», Taras Shevchenko National University of Kyiv 64/13, Volodymyrska Str., Kyiv, Ukraine, 01601

${ }^{3}$ Institute of Bioorganic Chemistry and Petrochemistry, NAS of Ukraine

50, Kharkivske Schose, Kyiv, Ukraine, 02160

yasnenka@gmail.com

\begin{abstract}
Aim. To develop the porous functionalized collagen scaffold for the delivery of FGF-2 and studying its properties in vitro and in vivo. Methods. Porous collagen scaffolds were prepared by freeze-drying collagen I solutions containing the polymer developed on the basis of cross-linked modified heparin. The scaffolds have been analyzed by SEM, AFM and SCLM. The angiogenic activity of these scaffolds loaded with FGF-2 was tested in a CAM assay. Results. The data obtained by SEM and SCLM analysis revealed that the scaffold mainly has a layered structure with pores forming a connection between the layers. The average pore size of the scaffolds varied from 76 to $150 \mu \mathrm{m}$. Scaffolds containing the polymer were able to incorporate human FGF-2. Proposed compositions promoted angiogenesis in CAM assay. Conclusions. The developed porous functionalized collagen scaffold incorporating FGF-2 can be used as a vehicle for the sustained delivery of the growth factor both in vitro and in vivo.
\end{abstract}

Keywords: hydrogel, fibroblast growth factor, angiogenesis, collagen, heparin.

Introduction. A variety of human pathologies such as critical limb ischemia, venous stasis, stroke, angina, infarction, diabetic ulcers, etc. are the consequences of severe blood flow violation resulted in the tissue ischemia. These pathologies are among the major causes of human morbidity and mortality. For example, according to different estimations, the peripheral arterial disease alone affects up to $10 \%$ of people worldwide, rising to $15-20 \%$ in humans after 70 years. In Europe and North America around 27 million people are affected [1]. The existing therapeutic and surgical approaches for the correction of vessel beds do not always result in a proper reconstitution of the blood flow, and, as a consequence, fail to restore the functional state of the damaged tissues. Various studies have proven that the

(c) Institute of Molecular Biology and Genetics, NAS of Ukraine, 2014 administration of several proangiogenic growth factors can induce and enhance the neovascularization in the injured tissues [2, 3]. Since FGF-2, as well as FGF-1, is a potent mitogen and chemoatractant for fibroblasts, as well as for endothelial cells, it appears to be a strong candidate as a potentiating agent for therapeutic angiogenesis $[4,5]$. However, the FGF-2 application is limited by the need to maintain its prolonged local release at the levels sufficient to stimulate angiogenesis. The stabilization of the newly formed vessels is another problem to be solved. It has been demonstrated that several components of the extracellular matrix, for example collagen I, could stabilize the vessels [6,7]. Thus, the development of a vehicle that can maintain the sustained release of the FGF-2, stabilize de novo formed vessels, and provide a temporary support for the cells migrating to the damaged site, can enhance the thera- 
peutic angiogenesis, and restore appropriate blood flow in ischemic tissue.

The present study focuses on the development of a porous functionalized collagen-based scaffold for the delivery of FGF-2 and on its properties in vitro and in vivo.

Materials and methods. Type I collagen was extracted from bovine tendons, all materials were kept at $-20{ }^{\circ} \mathrm{C}$. Type I collagen was extracted using the pepsin-based acidic extraction method described by Zeugolis et al. [ 8], lyophilized, and stored at $-20{ }^{\circ} \mathrm{C}$ for further application. Collagen extracts were analyzed by SDS-PAGE according to the Laemmli method [9] using $10 \%$ separating gels. Recombinant human FGF-2 was supplied by «Interpharmbiotek» (Ukraine). Heparin was obtained from «BIOFER SpA» (Italy), 1-ethyl-3-(3-dimethylaminopropyl)carbodiimide hydrochloride (EDC) and adipic dihydrazide were from «Sigma-Aldrich» (USA).

Preparation of the cross-linked heparin. $100 \mathrm{mg}$ of heparin and $15 \mathrm{mg}$ of adipic dihydrazide were dissolved in $450 \mu \mathrm{l}$ of water, and the $\mathrm{pH}$ was adjusted to 4.2 4.5 with diluted hydrochloric acid. Then EDC carbodiimide $(30 \mathrm{mg})$ was added and quickly dissolved in the reaction mixture, the hydrogel formation started in 20 $30 \mathrm{~s}$. The mixture was kept for $30 \mathrm{~min}$ at room temperature. The gel was crushed, and extensively washed with water followed by ethanol. After each washing step the polymer was collected by centrifugation. The resulting material was vacuum dried. Prior to use, the polymer was suspended in saline and sonicated.

MTT assay. The influence of the developed polymer on the viability of CHO-K1 cells was tested in the colorimetric MTT metabolic activity assay. CHO-K1 cells $\left(1 \cdot 10^{4}\right.$ cells per well) were cultured at $37{ }^{\circ} \mathrm{C}, 5 \%$ $\mathrm{CO}_{2}$ in the presence of polymer in varying concentrations for $72 \mathrm{~h}$. The cells treated with complete culture medium (F-10 culture medium («Sigma-Aldrich»), containing $10 \%$ of embryonic calf serum («Sigma»), 100 $\mathrm{U} / \mathrm{ml}$ of penicillin, and $100 \mu \mathrm{g} / \mathrm{ml}$ of streptomycin) only served as a negative control group. The assay was performed according to the method by Denizot et al. [10]. The experiment for each concentration point was performed in triplicate. The relative cell viability was expressed as a percentage to the control cells treated with a complete culture medium. To assess significance of the discrepancies we used the non-parametric criterion of Mann-Whitney $(U)$.

Fabrication of porous functionalized collagen scaffolds. Porous collagen scaffolds were prepared by freeze-drying the collagen solution $(10 \mathrm{mg} / \mathrm{ml})$ in $0.1 \mathrm{M}$ acetic acid, containing $1 \mathrm{mg} / \mathrm{ml}$ of the developed heparin polymer. The scaffolds were stored at $-20{ }^{\circ} \mathrm{C}$ for further application.

Swelling studies. Dried pieces of the scaffolds were used to determine the water uptake. The ratio of water absorption $\left(W_{a}\right)$ was determined by immersing the matrices $\left(0.25 \mathrm{~cm}^{2}\right)$ into 0.1 M HEPES pH $7.2(0.5 \mathrm{ml})$ for $24 \mathrm{~h}$ soak at $4{ }^{\circ} \mathrm{C}$. Afterwards, they were removed from the solution, blotted with filter paper, and weighed. $W_{a}$ was calculated using the following equation [11]: $W_{a}$ $(\%)=\left(W_{s}-W_{d}\right) / W_{s} \cdot 100$, where $W_{s}$ - the weight of the swollen sample, $W_{d}$ - the weight of dried sample.

Loading/release of FGF-2. FGF-2 was dissolved in PBS to the final concentration of $0.2 \mathrm{mg} / \mathrm{ml}$. The sample was pre-weighed, UV-treated and swollen overnight in 0.1 M HEPES $\mathrm{pH}$ 7.4. Subsequently the matrices were immersed into $0.1 \mathrm{ml}$ of the FGF-2 solution for 24 $\mathrm{h}$ at $4{ }^{\circ} \mathrm{C}$. After withdrawing the solution, the remaining matrices were washed once with $0.5 \mathrm{ml}$ of saline, immersed into $0.1 \mathrm{ml}$ of F-10 («Sigma»), chosen as a release medium, and incubated at $37{ }^{\circ} \mathrm{C}$. In certain time intervals the immersion medium was changed with the same volume of fresh one. The FGF-2 content in the matrices and media was analyzed by SDS-PAGE. The quantity of FGF-2 in the samples studied was determined by densitometry of polyacrylamide gel electrophoregrams. For this purpose the SDS-PAGE gels were stained with Coomassie Brilliant Blue according to [9], documented by ChemiDoc ${ }^{\mathrm{TM}}$ XRS+ System («BioRad», USA), and subsequently analyzed with «Image Lab Software ${ }^{\mathrm{TM}} »(«$ Bio-Rad»).

Cell culture. The CHO-K1 cell line was obtained from the Russian cell culture collection [12]. The cells were cultured in the F10 culture medium («Sigma-Aldrich»), containing $10 \%$ of fetal calf serum («Sigma»), $100 \mathrm{U} / \mathrm{ml}$ of penicillin, and $100 \mu \mathrm{g} / \mathrm{ml}$ of streptomycin. In order to test the viability and distribution of the mammalian cells cultured on developed scaffolds, $1 \cdot 10^{6} \mathrm{CHO}-$ $\mathrm{K} 1$ cells were seeded on $1 \mathrm{~cm}^{2}$ of a porous scaffold.

Scanning electron microscopy (SEM). The freezedried samples of developed matrices were coated with a 

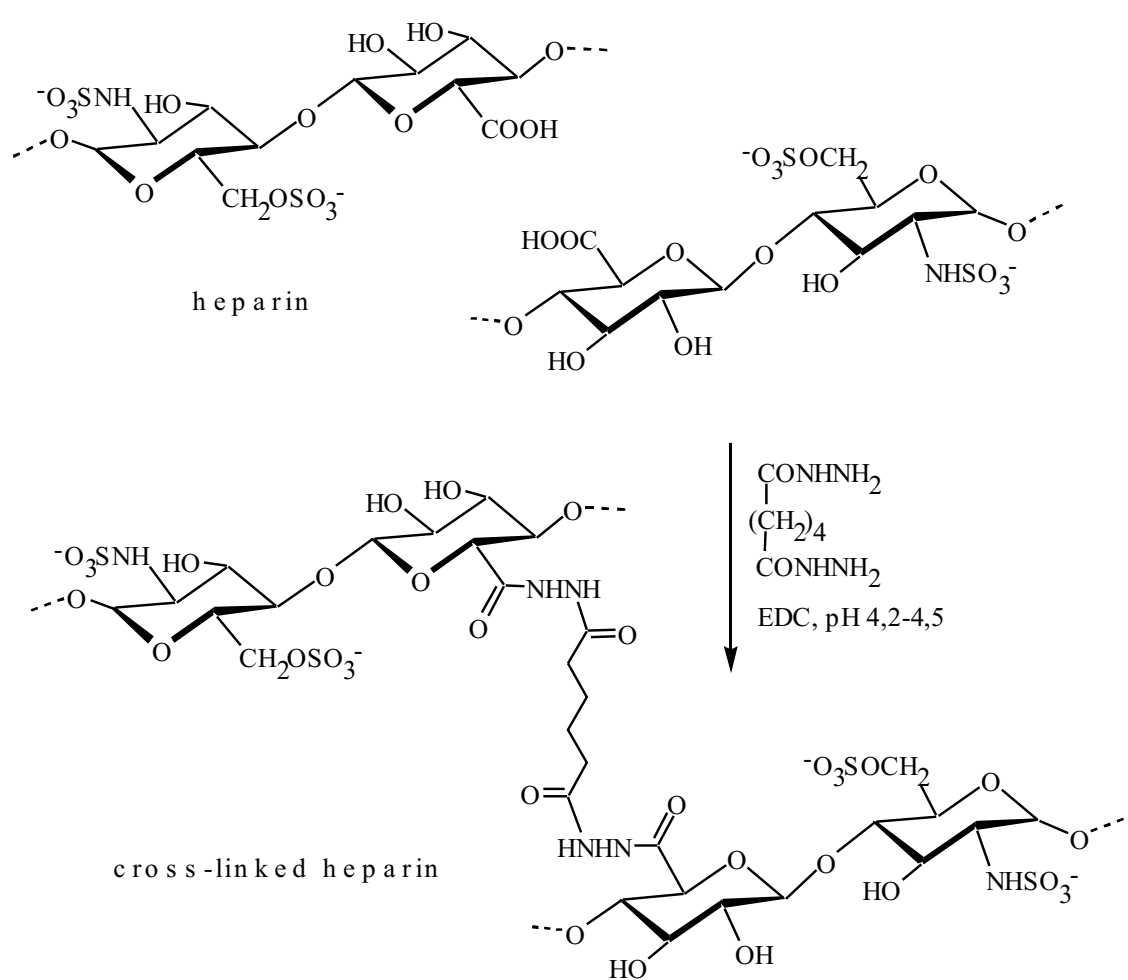

Fig. 1. Scheme of cross-linking heparin with adipic dihydrazide. EDC - water-soluble carbodiimide
$10-30 \mathrm{~nm}$ thick gold-metal layer to improve the surface conductivity, and examined for morphological details with the Jeol JSM 35C and Jeol JSM 6060LA scanning electron microscopes (Tokyo, Japan).

Confocal microscopy. The morphological details of the matrices in solution and distribution of the seeded cells were studied using the confocal scanning microscope AXIOSKOP-2 ZEISS with the laser scanning program LSM 510 PASCAL («Carl Zeiss», Germany).

AFM imaging. All measurements were performed using the AFM NT-206 atomic force microscope (Belarus). The images were obtained using triangular silicon cantilevers (NSC 11) with a nominal spring constant of $48 \mathrm{~N} / \mathrm{m}$, frequency $372.329 \mathrm{kHz}$. Tip curvature radius was $<10 \mathrm{~nm}$. The scaffolds were equilibrated with 0.1 M HEPES (pH 7.4), and then placed on a glass substrate and incubated in air for 2 days at room temperature before the study.

CAM assay. The ability of the developed functionalized scaffolds loaded with FGF-2 to induce angiogenesis in vivo was studied with a modified chorioallantoic membrane (CAM) assay according to the method described by Wilting et al. [13].

Results and discussion. The main common feature of the proteins belonging to the FGF family is their ex- traordinarily high affinity to heparin and heparin sulfate proteoglycans $[14,15]$. The binding of FGF-2 to heparin sulfate proteoglycans on the cell surface serves as a mechanism for creating storage site for the proteins, from which they could be released when needed. Additionally, the interactions with heparin could stabilize these proteins and potentiate their angiogenic activity. Therefore we chose to develop a carrier for FGF-2 based on heparin.

Heparin is a natural water-soluble polysaccharide consisting of the units of glucuronic acid and sulfoglucosamine. The presence of numerous carboxylic groups allows easy functionalization and modification of this polymer. We have developed a convenient protocol for its cross-linking, based on the reaction of heparin with a known bifunctional reagent, adipic dihydrazide (10$20 \%$ by weight), in the presence of water-soluble carbodiimide in aqueous medium at slightly acidic $\mathrm{pH}$. The reaction proceeds via the formation of hydrazide bonds between the $\mathrm{COOH}$ functions of the polysaccharide chains and a cross-linking reagent (Fig. 1). The process is fast and results in the formation of a sufficiently stable heparin hydrogel which is insoluble in water. The optimal properties of the polymer were achieved at a content of $15 \%$ of the cross-linking reagent. 


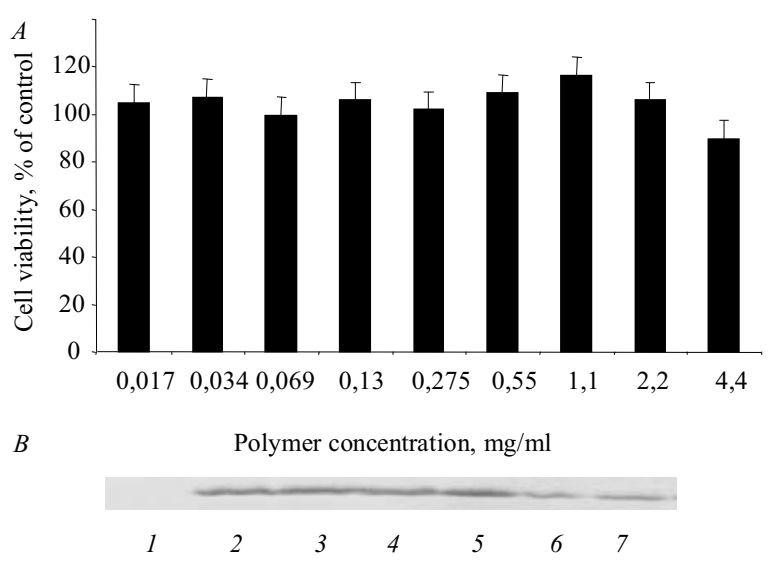

Fig. 2. $A$-dose-response viability of $\mathrm{CHO}-\mathrm{K} 1$ cells cultured in the presence of developed polymer detected by MTT-assay. The viability of CHO-K1 cells after $72 \mathrm{~h}$ treatment with polymer. Each value was calculated from three samples and presented as mean $\pm \mathrm{SD} ; B$ analysis of FGF-2 loading on the developed polymer by SDS-PAGE (after $1 \mathrm{~h}$ of incubation at $\left.22^{\circ} \mathrm{C}\right)(1$ - supernatant; $2-5$ - pelleted polymer; 6-7 - recombinant FGF-2 marker

The influence of the developed polymer on the viability of mammalian cells was studied with the CHO$\mathrm{K} 1$ cell line. The viability of these cells was assayed after $72 \mathrm{~h}$ of exposition with a common MTT assay, which demonstrated that the polymer did not substantially change the metabolic activity of CHO-K1 cells at any concentration tested (Fig. 2, A). The incubation at the highest polymer concentration $(4.5 \mathrm{mg} / \mathrm{ml})$ slightly reduced the cell viability, though not significantly. For future studies we have chosen the concentrations below $1 \mathrm{mg} / \mathrm{ml}$. FGF-2 loaded on the obtained polymer binds effectively after 1 hour of co-incubation in saline at 22 ${ }^{\circ} \mathrm{C}$ (Fig. 2, B). The maximum binding capacity under these conditions was observed at the polymer concentration of $12-15 \mu \mathrm{g}$ of FGF-2 per $1 \mathrm{mg}$ of the polymer. An efficient scaffold should be highly porous with large surface/volume ratio to accommodate a large number of cells in order to facilitate the migration of the cells into the functionalized collagen scaffold containing FGF-2. This allows neovascularization of the matrix and stabilizes the formation of vessel network. The functionalized collagen scaffold was created by freeze-drying the collagen I solution containing the developed polymer for the FGF-2 incorporation. The scaffolds were analyzed by SEM and SCLM to study the structure obtained in dried state as well as in solution. For the SCLM studies the scaffolds were firstly sterilized by UV, immersed in 0.1 M HEPES buffer (pH 7.4) for $24 \mathrm{~h}$ at $4{ }^{\circ} \mathrm{C}$, and then equilibrated with the F-10 culture medium for additional $24 \mathrm{~h}$. These data revealed that the scaffold had a layered structure with pores connecting the layers. The average pore size of the developed scaffolds varied in the range of $76-150 \mu \mathrm{m}$ (Fig. 3, $A, C$ ) in dried state, and did not change significantly in solution. The distribution of the polymer particles in the developed scaffold was studied by AFM and SCLM. Both demonstrated that the particles are located densely within the scaffold. The analysis of AFM images revealed the presence of large aggregates consisting of separate granules (the size varied between 165 and $364 \mathrm{~nm}$ ), and their distribution pattern was not uniform (Fig. 3, B).

As shown before, the scaffold swelling properties significantly influence cell behavior (namely adhesion, growth, differentiation), and directly affect the diffusion rate for any nutrients necessary for the growth of cells within the scaffold. The swelling studies demonstrated that the water uptake by the scaffolds was $1569 \%$. which indicates that the scaffold will provide appropriate conditions for the cells and easily absorb fluid and donate moisture if placed directly into the wound. A high water content could be explained by the hydrophilic nature of both the collagen and the heparin-based hydrogel, as well as by a high porosity of sponges which are meant to hold the water inside the pores. The heparinbased polymer within the scaffolds preserved its ability to incorporate the recombinant human FGF-2. The average binding capacity under these conditions was 50 $\mu \mathrm{g} / \mathrm{cm}^{2}$ of the scaffold, while unmodified collagen scaffold was able to absorb only $0.94 \mu \mathrm{g} / \mathrm{cm}^{2}$ of the protein due to the retention of FGF-2 within the pores.

As stated before, in order to induce angiogenesis in the ischemic tissue efficiently, the carrier has to release FGF-2 for a long time at the site of its administration. We have studied the FGF-2 release from the developed scaffold immersed in $0.1 \mathrm{ml}$ of F-10 chosen as a release medium, and incubated at $37^{\circ} \mathrm{C}$. Fig. 3 shows a release profile for FGF-2 from the developed scaffold as a cumulative amount of the protein released in time. All samples exhibited a fast release of FGF-2 in the first $3 \mathrm{~h}$ of incubation, and then a relatively steady and slow release for up to 3 days ( 72 h) (Fig. 4). The initial fast release has to be attributed to FGF-2 trapped inside the pores of the scaffold, but not directly adsorbed onto the developed polymer. It could be confirmed by the fact 

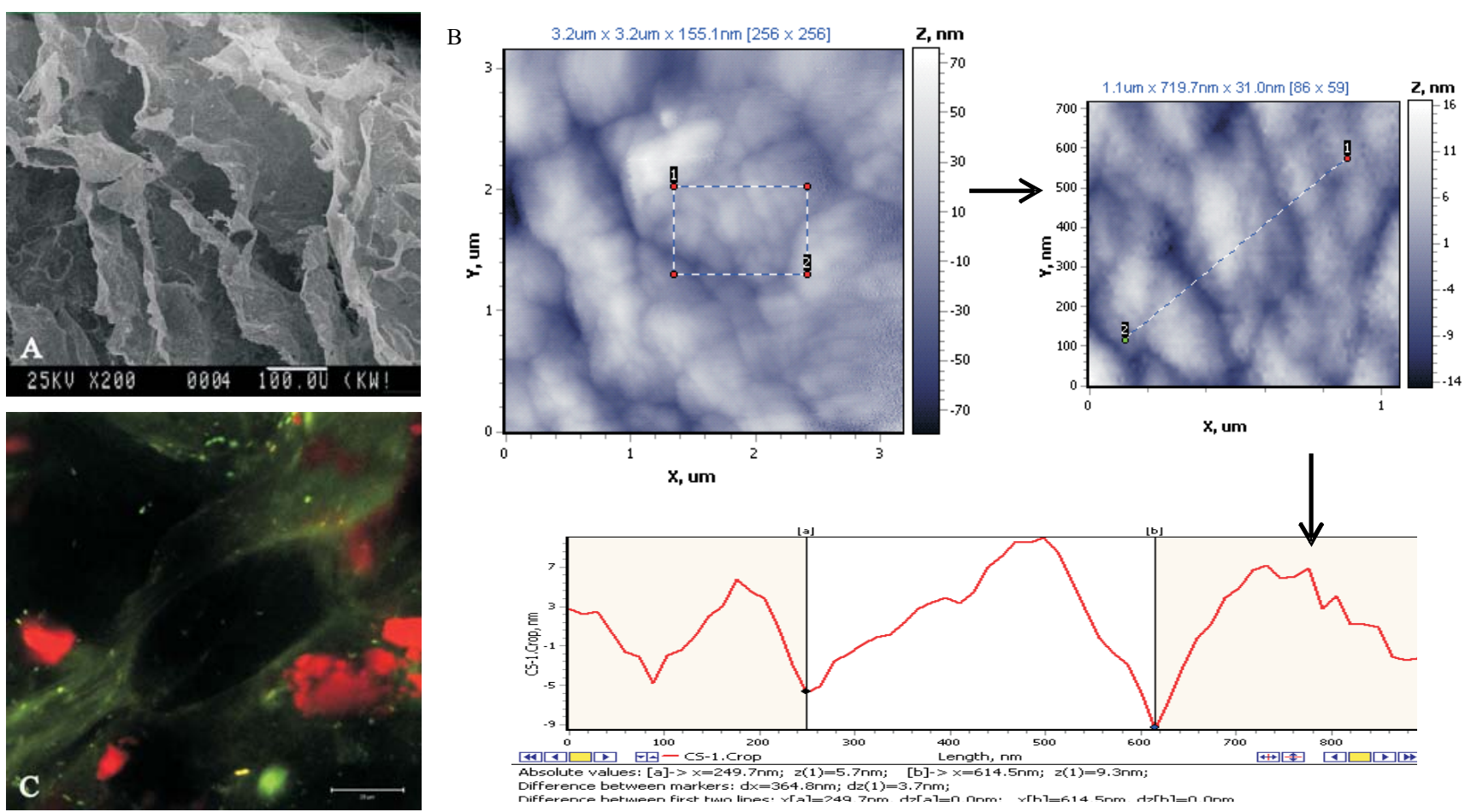

Fig. 3. Images of developed functionalized collagen scaffolds: $A-$ SEM image (scale bar $=100 \mu \mathrm{m}$ ); $B-$ AFM image: interior view of scaffold; $C-$ SCLM image (double staining-acridine orange and ethidium bromide, scale bar $=20 \mu \mathrm{m}$ ); the polymer particles are stained in red

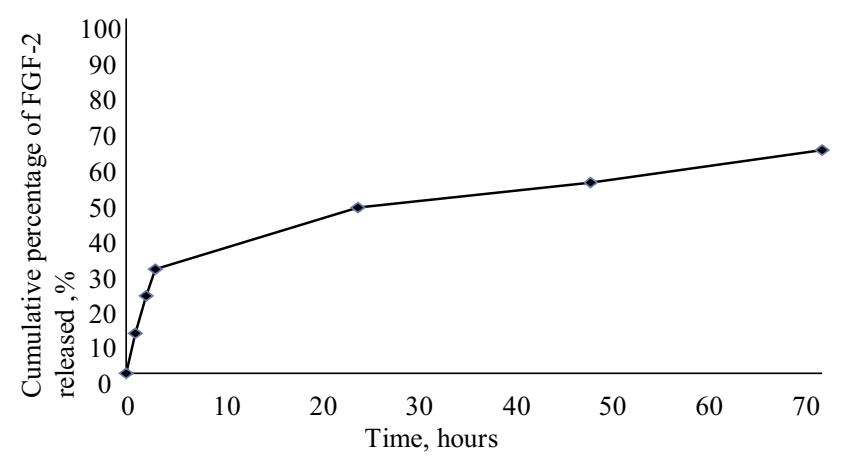

Fig. 4. Accumulative release of FGF-2 from developed functionalized collagen scaffolds in vitro. Scaffolds were incubated in F-10 medium at $37^{\circ} \mathrm{C}$. Each value was calculated from 9 samples
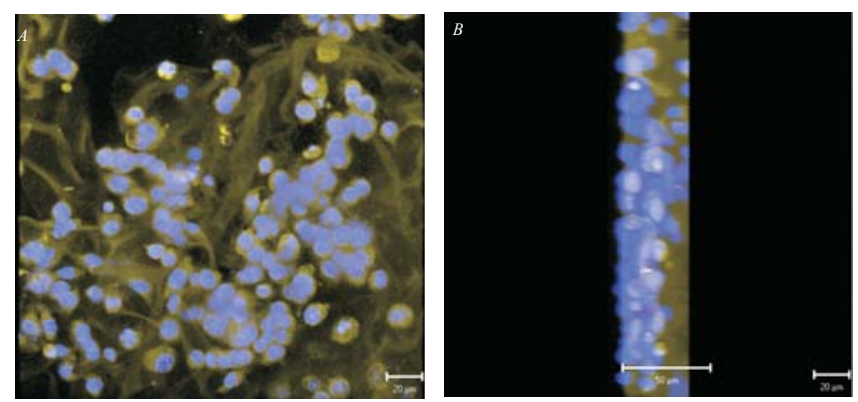

Fig. 5. $A$ - SCLM image of double stained CHO-K1 cells cultivated on the developed functionalized scaffold; $B$ - partial cross-section of the collagen scaffold with CHO-K1. Culture time was 6 days (Staining DAPI + Thiazine red) that we have observed a complete release of FGF-2 from the control scaffold made only of collagen during the first $3 \mathrm{~h}$ of incubation.

To assess the ability of the developed scaffolds to promote cell adhesion and growth, the CHO-K1 cells were seeded on the scaffold. The cells were incubated in the complete culture medium for 6 days. The cells became attached to the scaffold in $30 \mathrm{~min}$, and after 6 days in culture a significant increase in cell number was observed, which proved their proliferative activity (Fig. $5, A)$. The data obtained by SCLM revealed that the colonization of the scaffold extends not only over the surface, but also inside the matrix (Fig. 5, B). Thus, on the basis of data obtained one can suggest that the developed functionalized collagen scaffolds would support not only cell growth, but also migration and colonization of the scaffolds both in vitro and in vivo.

It is generally known that FGF-2 has a powerful pro-angiogenic activity, but could potentially lose this biological activity when loaded onto the different carriers. Thus, the ability of the developed functionalized scaffolds loaded with FGF-2 to induce the angiogenesis in vivo was studied by a CAM assay. The angiogenic activity of the scaffolds was determined after three 


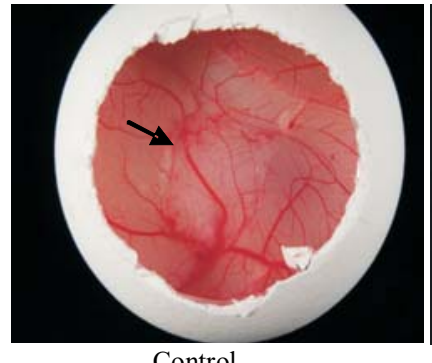

Control

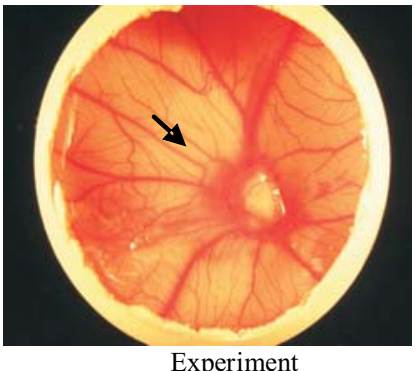

Experiment
Fig. 6. Angiogenic activity of the developed scaffold with FGF-2 in the CAM assay. The developed scaffolds containing FGF-2 were placed on CAMs of the 8-day-old chicken embryos. Places of application are indicated by arrows. Empty scaffold was used as a negative control

days of incubation. The controls treated with an empty vehicle showed a large blood vessel without any significant sprouts. In contrast, a vehicle loaded with $1 \mu \mathrm{g}$ of FGF-2 elicited a strong angiogenic response (Fig. 6), which leads to the conclusion that FGF-2 loaded on the developed scaffold did not lose its biological activity, and can be tested for the induction of angiogenesis in vi$v o$ in different ischemic animal models.

Conclusions. The present study focuses on the development of a functionalized collagen scaffold for the delivery of FGF-2, which can not only provide a sustained release of the growth factor in vivo but also help to stabilize the newly formed vessels. The FGF-2 polymer carrier based on modified cross-linked heparin has been developed, and the functionalized collagen scaffolds with layered structure, interconnected by the pores of $76-150 \mu \mathrm{m}$ in diameter were produced by the freeze-drying technique. The swelling tests showed a high water uptake of the scaffolds, which indicates that the scaffold is able to provide appropriate conditions for the cells.

The study revealed that the average binding capa city, under the conditions that were tested, was $50 \mu \mathrm{g} /$ $\mathrm{cm}^{2}$ of the scaffold. All samples exhibited a fast release of FGF-2 in the first three hours of incubation, and then a steady and slow release for up to three days. The developed functionalized collagen scaffolds supported not only cell growth, but also migration and colonization of scaffolds in vitro. Lastly, the vehicles loaded with FGF-2 strongly elicited an angiogenic response in the CAM assay.

Thus, these results indicate that the proposed functionalized collagen scaffolds loaded with FGF-2 can be used as a vehicle for the sustained delivery of the growth factor both in vitro and in vivo.

Acknowledgements. The authors thank to Prof. Geert Potters for his valuable assistance in the publication of the current work.

Створення та дослідження властивостей пористих функціоналізованих колагенових скафолдів для доставки FGF-2

Я. О. Похоленко, М. Д. Четирікна, Л. В. Дубей, І. Я. Дубей, О. В. Мошинець, Є. В. Шелудько, С. П. Шпильова,

М. І. Дегтярева, В. А. Кордюм

Резюме

Мета. Розробка пористих функціоналізованих колагенових скафолдів для доставки FGF-2, а також вивчення їхніх властивостей in vitro ma in vivo. Методи. Пористі колагенові скафолди одержано методом ліофільного сублімаційного висушування розчину колагену типу I, який містить створений полімер на основі модифікованого зиитого гепарину. Скафолди аналізували методами СЕМ, АСМ і ЛСКМ. Ангіогенні властивості колагенових скафолдів, які містять FGF-2, вивчали на моделі хоріон-алантоїсноі мембрани ембріона курчати. Результати. Дані, отримані методами СЕМ і ЛСКМ, свідчать про те, шуо одержаний скафолд має перважно шарувату структуру з порами, які з'єднують різні шари. Середній розмір пор варіює від 76 до 150 мкм. Скафолди, до складу яких входить створений полімер, здатні адсорбувати рекомбінантний FGF-2 людини. Запропоновані композииї стимулюють ангіогенез на моделі хоріон-алантоїсної мембрани ембріона курчати. Висновки. Розроблені пористі функціоналізовані колагенові скафолди, які містять FGF-2, можна використовувати як засіб для доставки даного ростового фактора, що забезпечує його тривале вивільнення як іn vitro, так in vivo.

Ключові слова: гідрогель, фактор росту фібробластів-2, ангіогенез, колаген, гепарин.

Создание и изучение свойств пористых функционализированных коллагеновых скаффолдов для доставки FGF-2

Я. А. Похоленко, М. Д. Четыркина, Л. В. Дубей, И. Я. Дубей,

Е. В. Мошинец, Е. В. Шелудько, С. П. Шпилевая,

М. И. Дегтярева, В. А. Кордюм

Резюме

Цель. Разработка пористых функционализированных коллагеновых скаффолдов для доставки FGF-2 и изучение их свойств іп vitro $u$ in vivo. Методы. Пористые коллагеновые скаффолды получены методом лиофильной сублимачионной сушки раствора коллагена типа I, содержащего созданньй полимер на основе модифииированного сшитого гепарина. Скаффолды анализировали методами СЭМ, АСМ и ЛСКМ. Ангиогенные свойства разработанных коллагеновых скаффолдов, содержащих FGF-2, изучали на модели хорион-аллантоисной мембрань куриного эмбриона. Результаты. Данные, полученные методами СЭМ и ЛСКМ, свидетельствуют о том, что созданный скаффолд в основном имеет слоистую структуру с порами, соединяющими разные слои. Средний размер пор варьирует от 76 до 150 мкм. Скаффолды, содержащие полученный полимер, способны адсорбировать рекомбинантный FGF-2 человека. Предложенные композиции стиму- 
лируют ангиогенез на модели хорион-аллантоисной мембраны куриного эмбриона. Выводы. Разработанные пористье функциона лизированные коллагеновые скаффолды, содержащие FGF-2, можно использовать как средство для доставки данного ростового фактора, обеспечивающее его длительное высвобождение, как in vitro, так in vivo.

Ключевые слова: гидрогель, фактор роста фибробластов-2, ангиогенез, коллаген, гепарин.

\section{REFERENCES}

1. Peach $G$, Griffin M, Jones KG, Thompson MM, Hinchliffe RJ. Diagnosis and management of peripheral arterial disease. $B M J$. 2012;345:e5208.

2. Cheng $X$, Wang Z, Yang J, Ma M, Lu T, Xu G, Liu X. Acidic fibroblast growth factor delivered intranasally induces neurogenesis and angiogenesis in rats after ischemic stroke. Neurol Res. 2011;33(7):675-80.

3. Daugherty AL, Rangell LK, Eckert R, Zavala-Solorio J, Peale F, Mrsny RJ. Sustained release formulations of $\mathrm{rVEGF}_{165}$ produce a durable response in a murine model of peripheral angiogenesis. Eur J Pharm Biopharm. 2011;78(2):289-97.

4. Chen CH, Poucher SM, Lu J, Henry PD. Fibroblast growth factor 2: from laboratory evidence to clinical application. Curr Vasc Pharmacol. 2004;2(1):33-43.

5. Tanaka E, Ase K, Okuda T, Okumura M, Nogimori K. Mechanism of acceleration of wound healing by basic fibroblast growth factor in genetically diabetic mice. Biol Pharm Bull. 1996;19(9): 1141-8.

6. Francis ME, Uriel S, Brey EM. Endothelial cell-matrix interactions in neovascularization. Tissue Eng Part B Rev. 2008;14(1): 19-32.

7. Francis-Sedlak ME, Moya ML, Huang JJ, Lucas SA, Chandrasekharan N, Larson JC, Cheng MH, Brey EM. Collagen glycation alters neovascularization in vitro and in vivo. Microvasc Res. 2010;80(1):3-9

8. Zeugolis DI, Li B, Lareu RR, Chan CK, Raghunath M. Collagen solubility testing, a quality assurance step for reproducible electrospun nano-fibre fabrication. A technical note. J Biomater Sci Polym Ed. 2008;19(10):1307-17.

9. Sambrook J, Fritsch EE, Maniatis T. Molecular cloning. Cold Spring Harbor Lab. press, 1989; 625 p.

10. Denizot $F$, Lang $R$. Rapid colorimetric assay for cell growth and survival. Modifications to the tetrazolium dye procedure giving improved sensitivity and reliability. J Immunol Methods. 1986; 89(2):271-7.

11. Park SN, Park JC, Kim HO, Song MJ, Suh H. Characterization of porous collagen/hyaluronic acid scaffold modified by 1-ethyl3-(3-dimethylaminopropyl)carbodiimide cross-linking. Biomaterials. 2002;23(4):1205-12.

12. Catalogue Russian cell culture collection (RCCC). St. Petersburg: OMSK, 1999; 80 p.

13. Wilting J, Christ B, Bokeloh M. A modified chorioallantoic membrane (CAM) assay for qualitative and quantitative study of growth factors. Studies on the effects of carriers, PBS, angiogenin, and bFGF. Anat Embryol (Berl). 1991;183(3):259-71.

14. Seno M, Sasada R, Kurokawa T, Igarashi K. Carboxyl-terminal structure of basic fibroblast growth factor significantly contributes to its affinity for heparin. Eur J Biochem. 1990;188(2): 239-45.

15. Coltrini D, Rusnati M, Zoppetti G, Oreste P, Isacchi A, Caccia P, Bergonzoni L, Presta $M$. Biochemical bases of the interaction of human basic fibroblast growth factor with glycosaminoglycans. New insights from trypsin digestion studies. Eur J Biochem. 1993;214(1):51-8. 